\title{
Agrobacterial transformation of maize by in planta and in vitro methods: problems and decisions
}

Fadeev V.V., Mazilov S.I., Ulyanov A.V., Gusev Yu.S., Chumakov M.I.

Institute of biochemistry and physiology of plants and microorganisms, Russian Academy of Sciences, Saratov, Russia E-mail:vvf2593@gmail.com

Annotation. Problems of agrobacterial transformation of maize by methods in planta and in vitro are described. Experimental data on optimization of regeneration from transformed embryogenic maize callus of the KM line are presented. Keywords: maize, Agrobacterium-mediated transformation, regeneration, embryogenic callus

Relevance: currently, the Agrobacterium-mediated plant transformation method is widely used in modern biotechnology, including the CRISPR/Cas system.

Purpose: Regeneration the maize KM line plants from the immature embryo.

Results: The main problem with the agrobacterial transformation of maize by in planta method are the seasonality of maize flowering and temperature requirements. The effectiveness of maize transformation by the in planta method is also affected by the use of various agrobacterial strains and maize lines, the procedure for applying of agrobacterial cell-pollen suspension to the maize pistil filaments [1].

In the case of agrobacterial transformation of maize by in vitro method, one of the problems is to obtain an embryogenic callus from 10-12-day-old embryos. Not all maize genotypes regenerate well from callus cultures [2]. For each type of regenerated plant, it is necessary to select the environment for cultivation. For monocotyledonous plants, regeneration is complicated by a low morphogenic potential.

Experimental data showed that for optimal regeneration from the embryogenic maize callus, it is necessary to add $1 \mathrm{mg} / \mathrm{l}$ of 2,4-D and $15 \mathrm{~g} / \mathrm{l}$ of sucrose to the Murashige-Skoog (MS) medium. With such changes, regeneration was 2 times more intense, compared to the literature described MS media with a content of $1.5 \mathrm{mg} / \mathrm{l}$ of 2,4-D and $25 \mathrm{~g} / \mathrm{l}$ or $30 \mathrm{~g} / \mathrm{l}$ of sucrose. For rooting regenerants of maize for 3 weeks before planting into the soil, a gradual decrease in the content of sucrose was carried out, which contributed to the formation of adventitious roots. Experiments have shown that the optimal conditions for regeneration and growth were: illumination of 3000-4000 Lux with a 16-hour photoperiod, the temperature is $23-25{ }^{\circ} \mathrm{C}$.

The work was carried out under the program of fundamental scientific research of the state academies of Sciences for 2020 (№ AAAA-A17-117102740101-5) and with the financial support of grants from RFBR-a №20-016-00020 and RFBR-mol-e-a № 20-316-80020.

\section{Проблемы агробактериальной трансформации кукурузы методами in planta, in vitro} Фадеев В.В., Мазилов С.И., Ульянов А.В., Гусев Ю.С., Чумаков М.И.

Институт биохимии и физиологии растений и микроорганизмов Российской академии наук, Саратов, Россия

Аннотация. Описань проблемы агробактериальной трансформации кукурузы методами in planta, in vitro. Приведень экспериментальные данные оптимизации регенерации трансформированного эмбриогенного каллуса кукурузы линии КМ.

Ключевые слова: кукуруза, агробактериальная трансформаџия, регенерация, эмбриогенный каллус

Метод агробактериальный трансформации растений широко используется в современной биотехнологии. В том числе в одном из перспективных современных методов геномного редактирования (CRISPR/Cas9).

Целью исследования является описание проблем агробактериальной трансформации кукурузы методами in planta, in vitro, а также оптимизация регенерации из трансформированного эмбриогенного каллуса кукурузы линии КМ.

Главными проблемами агробактериальной трансформации кукурузы методом in planta являются: сезонность цветения кукурузы, трудность соблюдения оптимальной температуры. Эффективность трансформации зависит от использования различных штаммов агробактерий, линий кукурузы, способа и порядка нанесения суспензии агробактериальных клеток и пыльцы на пестичные нити [1].

При агробактериальной трансформации кукурузы методом in vitro, одной из проблем является трудность получение эмбриогенного каллуса из 10-12 дневных зародышей. Не все генотипы кукурузы хорошо регенерируют из каллуса [2]. Экспериментальные данные показали, что для оптимальной регенерации из эмбриогенного каллуса кукурузы линии КМ необходимо добавить в среду Мурасиге-Скуга (MC) 1 мг/л 2,4-D и 15 г/л сахарозы. При таких изменениях регенерация происходила в 2 раза интенсивнее, в сравнении с литературно описанными средами МС с содержанием 1,5мг/л 2,4-D и 25 г/л либо 30 г/л сахарозы. Для укоренения регенерантов на протяжении 3 недель до высаживания в почву, проводили постепенное снижение содержания сахарозы, что способствовало образованию придаточных корней. Подобраны оптимальные условия для регенерации и выращивания: освещённость $3000-4000$ люкс, 16 часовой фотопериод, температура $23-25^{\circ} \mathrm{C}$

Работа выполнена по программе фундаментальных научных исследований государственных академий наук на 2020 г. (№ гос. регистрации АААА-А17-117102740101-5) и при финансовой поддержке грантов РФФИа №20-016-00020 и РФФИ-мол-э-а № 20-316-80020.

1. Чумаков М.И., Рожок Н.А., Великов В.А., Тырнов В.С., Волохина И.В. Генетика. 2006. Т. 42, №8. С $1083-1088$.

2. O'Kennedy M., Lotter-Stark H., Dube N. Methods in molecular biology (Clifton, N.J.) 2011. 710. 343-54. 